\title{
Good Faith In Arbitration Resolution In Indonesia
}

\author{
NOVRAN HARISA
}

\author{
Universitas Muhammadiyah Bengkulu, Jl. Bali Street Bengkulu 38119, Indonesia \\ email: novranharisa1@gmail.com
}

\begin{abstract}
Good faith plays an important role in realizing final and binding arbitration decisions. Without good faith, the arbitration award is very difficult to be implemented immediately. Thus, the purpose of this article is to analyze the implications of good faith in resolving disputes through arbitration. The method used is normative juridical research. The nature of the study is descriptive analytics. The type of data in this study was carried out through library research. The conclusion of this article is that good faith must cling to the agreement, meaning that it is ready to accept and implement the legal consequences arising from the agreement. There are 2 types of efforts to avoid the implementation of final and binding arbitral awards: the request for cancellation of the principal agreement and the request for cancellation of the award by seeking reasons outside the provisions of Article 70 of Law Number 30 of 1999. Efforts to overcome the harm in good faith as a method of dispute resolution are associated with the goal of realizing legal certainty by adding a special procedure like dismissal in the arbitration procedure.
\end{abstract}

Keywords: Arbitration, Good Faith, Dispute.

\section{Introduction}

Trading activity is one form of legal relations of engagement that was born because of the agreement. The agreement begins with negotiations (bargaining process) of the parties so as to produce an agreement as stated in the trade contract. Trading contracts can be said to be lawful if they meet the legal requirements of the agreement stipulated in Article 1320 of the Civil Code, namely agreeing that they are binding themselves, capable of making an agreement, certain things and a reason that is lawful (Subekti, 2002: 15).

In a trade contract (business) there is always a possibility of conflict or dispute arising from a conflict of interest or negligence of one party in fulfilling the contents of the agreement. The more and broaden the trading activities are, the higher the frequency of disputes. This means that more and more disputes must be resolved. According to Salim (2010), a dispute is a conflict between two or more parties that starts from a different perception of ownership or property rights that can cause legal consequences between them. Business disputes require an effective and efficient settlement so as not to cause harm to the parties. In an effort to resolve the dispute, the law is needed to obtain justice. Initially, dispute resolution was carried out in a family manner. If the kinship method cannot provide the expected settlement, the parties will bring the dispute to court.

Arbitration is one method of resolving business disputes outside the court. Dispute resolution through arbitration developed rapidly after the 18th century with the birth of various international arbitration conventions and international arbitration and national arbitration centers. Almost every country already has a national arbitration center (Hutagalung, 2012: 135). Indonesia also has a national arbitration center called the Indonesian National Arbitration Board (BANI) established by the Indonesian Chamber of Commerce (KADIN).

Article 60 UUAAPS (Law on Arbitration and Alternative Dispute Resolution) states that the arbitration award is final and binding. This provision implies that an arbitration award cannot be filed with an appeal, cassation or reconsideration. This is one of the advantages possessed by arbitration because 
it can provide legal certainty effectively for the parties to the dispute and prevent the dispute from becoming prolonged. One of the BANI arbitrators said that the increased trust of business actors resolves disputes through arbitration because it is more closed than the court, and the decision is final and binding.

These factors are at the same time the superiority of arbitration which is the reason business people chooses dispute resolution through arbitration. On the other hand, arbitration also contains various weaknesses. The weakness is mainly regarding the absence of executive power in the arbitration award so that the execution must go through a court ruling. Although the use of arbitration institutions was born from an agreement agreed upon by the parties, in fact not all decisions made through this arbitration forum will give satisfaction to the parties. The defeated party will generally find a way to cancel the arbitration award. In this case, the court has a large role in developing arbitration. The court is asked to intervene when the arbitration process has been completed and one of the parties is unwilling to implement the arbitration award (Rajagukguk, 2000: 4). The arbitration institution cannot enforce an arbitral award; the court has the authority to force the party who refuses the arbitration decision to comply. In other words, the court has the authority to determine the execution of the award.

The existence of a court inconsistent attitude to the arbitration ruling has made business confidence in the courts in Indonesia lower. Besides that, the absence of good intentions from the parties in accepting the arbitrary award arbitrarily caused the parties to always look for loopholes to cancel the arbitration award that was not in accordance with their wishes. Efforts to reject the arbitration decision were made through various modes, such as trying to cancel the principal agreement, requesting the cancellation of the arbitration award for various reasons, and so forth. Even though, the use of arbitration as a dispute resolution institution is an option agreed upon by the parties and stated in the arbitration agreement. The arbitration authority would not exist without the arbitration agreement made by the parties.

Good faith plays an important role in realizing final and binding arbitration decisions. Without the goodwill of the parties, the arbitration decision is very difficult to be implemented immediately because the party without a good faith will always look for loopholes to cancel the arbitration decision that is not in line with his expectations. Seeing the urgency of good faith in arbitration, It is necessary to make strict arrangements regarding the limits of such good faith so that the superiority of arbitration as a method of resolving disputes outside the court can be maintained.

\section{Research Methodology}

In this study, the author uses a normative juridical approach. The method of legal research is conducted by examining library legal materials or secondary data. Normative juridical research, as explained by Marzuki (2005: 35), is a process of finding legal rules, legal principles, and legal doctrine to answer legal issues faced. This research is analyticalexplorative, carried out by examining library material or mere secondary data (Soekanto and Pamuji, 2009: 14). The nature of this research is descriptive analytical, which provides an overview or explanation of the subject and object of research as the results of the research conducted (Fajar and Achmad, 2010: 22). The type of data in this study is carried out through library research, which collects and examines library materials or secondary data consisting of primary legal materials, secondary legal materials, and tertiary legal materials (Coben and Olson, 1992: 1-3).

The results of secondary data collection are then processed by conducting data checking (editing), data marking (coding), and systematic data. As in normative juridical research, to obtain the desired research results and to reach the target, the data analysis is conducted in a qualitative juridical manner by using abstraction and interpretation of the law, then poured in the form of descriptions instead of numbers (Nasution, 2003: 128).

\section{Results And Discussions}

\section{Regulation of Good Faith in Law Num- ber 30 of 1999 concerning Arbitration and Alternative Dispute Resolution}

An arbitration agreement is the main requirement for parties to settle disputes through arbitration. The agreement was born from the will of the parties who made it. Therefore, it can be said that the use of arbitration institutions is a manifestation of the willingness of the parties. The consensus of the parties contained in a contract is the 
main basis of arbitration (Gautama, 1996: 27). With the consensus of the parties, the agreement raises the power of binding agreement as appropriate for the law. A person in a legal relationship becomes law for them (Fuller and Eisenberg, 1972: 112).

The principle of binding contract power is an important basis in the law that people must obey promises. In other words, this principle is the basis that the parties in the contract are bound or obliged to conduct the agreement. Juridically, this principle is recognized by Article 1338 paragraph (1) of the Civil Code. This article states that all agreements made legally apply as laws for those who make them (Khairandy, 2011: 39).

Without an arbitration agreement, arbitration settlement cannot be carried out. The focus of the arbitration agreement is solely aimed at the problem of resolving disputes arising from the agreement. The parties can agree on the resolution of disputes arising from the agreement to not to be submitted and examined by an official judicial body but will be resolved by a neutral private power body commonly referred to as 'referee' or 'arbitration'. The power of binding the arbitration agreement is born from the agreement of the parties based on the principle of freedom of contract. The principle of freedom of contract in the field of trade has been recognized by almost all countries. Freedom of contract is "the moral force behind contract as a promise. The parties are bound to their contracts because they have chosen to be" (Sharma, 2002: 11).

The main function of an arbitration agreement is as the source of authority from the arbitration court. In principle, an arbitration court can only exercise such power if the parties agree to give such power. The principle that has been generally accepted is that the agreement of the parties gave birth to the law. This principle also applies to the agreement of the parties contained in the arbitration agreement. Thus, it can be stated here that arbitration clauses originating from the parties' agreements are the law of the parties. Therefore, this agreement gave birth to the authority function of an arbitration body. Included in the legal scope of these parties is the determination of a number of arbitrators, appointment procedures for arbitrators, the extent of power, and how procedural and applicable law will be applied by an arbitration body (Redfern and Hunter, 1986: 24).
Based on the provisions of the Civil Code article 529-532, the terminology of bezitters with good intentions, buyers of goods with good intentions or others (as opposed to those with bad intentions) is good faith with subjective factors. A buyer with good faith is a person who buys goods with confidence that the seller is truly the owner of the item he bought. He did not know if he had bought from an unauthorized person. That's why he is called an honest buyer. In this element, good faith means honesty or clean.

The Civil Code interprets good faith as redelijkheid and billijkheid agreements (Patrik, 1994: 67). Redelijkheid is defined as what can be understood with common sense, while a billijkheid is propriety. Thus, redelijkheid and billijkheid are basically the principles of public order. Consequently, the parties may not include provisions in the agreement stating that the principle is not valid (Suryodiningrat, 1985: 114). The nature of general legal regulations on this interpretation places redelijkheid and billijkheid as good intentions in the objective sense (Prodjodikoro, 1981: 106).

The author believes that good faith is indeed located in the soul (inner) of a person, but good faith can be judged from the attitude (behavior) that is shown by someone outwardly. Associated with arbitration as a method of dispute resolution, researchers argue that the regulation of good faith in the Arbitration Act can be formulated in a limitative manner based on the criteria stated by experts and legislation. The limited arrangement is indeed impossible to provide a perfect understanding of good faith, but at least it can be a reference in assessing the actions of the parties in the implementation of the arbitration agreement.

The regulation of good faith in the UUAAPS is very inadequate because it only mentions "good faith" without giving any further arrangement of the intended good faith. Article 6 paragraph (1) Law No. 30 of 1999 states, "Civil disputes or differences of opinion can be resolved by the parties through alternative dispute resolution based on good faith overriding litigation settlement in the District Court."

The researcher believes that the formulation of good faith in arbitration agreement must at least formulate a minimum standard of understanding the good faith. It must be formulated as "the attitude or behavior adheres to the agreement to give 
the opponent the promise of his right and not to look for loopholes to escape from what has been agreed based on propriety and rationality. Sticking to the agreement means being ready to accept and implement legal consequences arising from the agreement. Whereas, not looking for loopholes to break away means acting not guilty, cunning, making it up, and doing inappropriate ways in a legal and social view as an effort to avoid the legal consequences of what has been agreed to cause harm to others."

\section{Form of Harming Good Faith in an Arbitration Agreement}

In Indonesian legal system, the final characteristics and binding of arbitration decisions are recognized imperatively in Article 60 of Law No. 30 of 1999, because there was no open appeal, appeal, or reconsideration of the decision. But in reality, there are disputes in business transactions that have been decided by arbitration bodies, especially international arbitration bodies, which have caused controversy and the implementation of their decisions is still protracted which leads to the image of weak legal certainty in Indonesia.

An arbitration agreement is an insurance agreement and is not inherent in one entity with the principal agreement. This arbitration agreement is only an additional agreement which often called an "arbitration clause". Because its existence is additional, the arbitration agreement does not affect the implementation of the principal agreement. Without an arbitration clause, the implementation of the principal agreement is not hindered. Similarly, the cancellation or disability of the arbitration agreement does not result in the cancellation or make the principal agreement defective (Sudiarto and Asyhadie, 2004: 71).

Provisions in Article 10 of Law No. 30 of 1999, especially letters (f) and (h), are related to the principle of separability in an arbitration agreement, namely an arbitration contract or clause that stands independently and is completely independent of the principal agreement. Therefore, if the principal agreement is deemed legal or invalid for any reason, the arbitration contract or clause is still considered valid and binding (Fuady, 2003). The principle of separation in Article 10 letters (f) and (h) Law No. 30 of 1999 basically to prevent the emergence of bad faith from one of the parties who intends to cancel the principal agreement with the aim of canceling the derivative agreement (arbitration clause) (Soemartono, 2003: 41).

In making an agreement, the parties basically put their trust that the other person has no bad faith. Based on that belief, they agreed to tie themselves into an agreement. The good faith of the parties should be maintained until the end of the agreement. In reality, the good faith of the parties can easily turn into a bad one when they find unexpected things. Parties who are unable to fulfill the promised achievements begin to look for loopholes to avoid legal consequences arisen.

The action of one of the parties attempting to cancel the principal agreement with the aim of canceling the arbitration agreement as an assessment agreement is a manifestation of injury to good faith. Although Law No. 30 of 1999 in article 10 has been regulated of and set the principle of separability, in practice, there are still a number of cases which ignore this principle. For example, the interim decision of Central Jakarta District Court No. 517/Pdt.G/1999/ PN.Jkt.Pst. December 13, 1999, for the case of PT. Paiton Energy against PT. State Electricity Company (Persero) which accepted the PLN's argument stating that the arbitration agreement was invalid and null and void because the agreement (principal) for the sale of electricity was against the law, the decency, and public order. Another case example is the sugar sale and purchase agreement between Indonesian businessman Yani Haryanto acting as a buyer with a British exporter E.D. \& F, Man Sugar Ltd. Sugar Quay London, as a seller. The agreement is stated in two forms of trade contracts, namely: Contract of White Sugar No. 7458, February 12, 1982, for buying and selling sugar as much as 300,000 metric tons; and Contract of White Sugar No. 7527, on March 23, 1982 to buy and sell sugar as much as 100,000 metric tons.

Associated with the arbitration agreement, the parties who agreed to settle the dispute through arbitration institutions which are believed to provide a fair verdict then turned against the arbitration award. Various attempts were made by those who were objected to arbitration ruling; one of which was to seek legal reasoning to cancel the principal agreement, and the reason was Code of Conduct in Article 1337 of the Civil Code which states: "A reason that is prohibited by law, or if it is contrary to good morality or public order." 
The action of parties to cancel the principal agreement with the aim of canceling the arbitration agreement as an assessment agreement. Although it has been regulated in article 10 of Law No. 30 of 1999 has set the principle of separability, in practice, there are still a number of cases which ignore this principle. For example, the Interim decision of Central Jakarta District Court No. 517/ Pdt.G/ 1999/ PN.Jkt.Pst. December 13, 1999, for the case of PT. Paiton Energy against PT. State Electricity Company (Persero). The decision is accepted by the PLN, the arbitration agreement is invalid and null and void because the agreement (principal) for the sale of electricity is against the law, decency and public order. Another example of sugar sale and purchase agreement between Indonesian businessman Yani Haryanto acting as a buyer with a British exporter E.D. \& F, Man Sugar Ltd. Sugar Quay London, as a seller. The agreements for trade contracts are: Contract for White Sugar No. 7458, February 12, 1982, for buying and selling sugar as much as 300,000 metric tons; and Contract for White Sugar No. 7527, on March 23,1982 , to buy and sell sugar as much as 100,000 metric tons.

Many factors encourage international business transaction actors to choose arbitration, including the reason that arbitration award is final and binding and therefore tends to be ready to carry out immediately. Moreover, the nature of arbitration guarantees the neutrality of the arbitration council chosen by the parties, meaning that there is no national character (Rajagukguk, 2000: 193-194). Those reasons are always taken into consideration by foreign parties who conduct business transactions in Indonesia. The first consideration is more towards the aspect of legal certainty, and the second is more aimed at avoiding the possibility of narrow nationalism occurring in national court judges (Juwana, 2002: 84).

\section{Efforts to Overcome the Harm of Good Faith to Maintain Arbitration Excellence as a Method of Dispute Resolution}

Dispute resolution through arbitration forums results in a final and binding arbitration award as a final decision and has a permanent legal force that binds the parties. Thus, it cannot be filed with an appeal, cassation, or reconsideration. This is one of the advantages of arbitration since it provides an effective legal certainty for the parties to the dispute and prevents the dispute from becoming prolonged.

It cannot be denied that in reality, not all decisions made through this arbitration forum will give satisfaction to the parties. In this case, the court has a large role in developing arbitration (Rajagukguk, 2000: 4). The law itself also allows for court interference in resolving disputes through arbitration, one of which is in the form of a request for the cancellation of an arbitration decision submitted to a district court. Parties who are not satisfied with an arbitration award shall submit a request for the cancellation of the arbitration award.

Basically, efforts to cancel the arbitration award itself are made possible in Law No. 30 of 1999 concerning Arbitration and Alternative Dispute Resolution in Article 70. Supreme Court in Decision No. 396 K/Pdt.Sus/2010 also emphasizes that cancellation of an arbitration decision can only be made based on the reasons in Article 70 of Law No. 30 of 1999. However, on the other hand, the Supreme Court in Decision No. 03/Arb/.Btl/2005 states that it is possible to cancel the arbitration decision on the grounds outside Article 70 of Law No. 30 of 1999. Law No. 30 of 1999 prohibits the involvement of the District Court to adjudicate disputes where the parties have been bound by the arbitration agreement. This is regulated in Article 3 of Law No. 30 of 1999.

The provisions of Article 3 are basically in line with the arrangements in the UNCITRAL Law Model which prohibits the existence of court interference in arbitration except for matters that have been regulated in the Law Model. The cancellation request for the award is submitted to the District Court. That is, the District Court has the authority to check whether the elements in Article 70 of Law No. 30 of 1999 have been fulfilled or not. Giving the right for the court to intervene in arbitration authority is possible if it can be proven that there are acts of forgery, fraud, or embezzlement as referred to in Article 70 of Law No. 30 of 1999. Based on these provisions, basically, the cancellation request for an arbitration award does not constitute an appeal as provided in the settlement of a dispute through a court. In principle, without any specific reasons, it is not possible to cancel an arbitral award. Disapproval or disappointment of one party will not be the reason for the cancellation (Fuady, 2003: 106). 
The practice of cancelling arbitral awards by the District Court to the Supreme Court is still experiencing inconsistencies, especially with regard to the use of reasons for the cancellation of the arbitration award in Article 70 of Law No. 30 of 1999. On the one hand, the Supreme Court affirms that cancellation of an arbitration decision can only be made based on the reasons stated in Article 70, but on the other hand the Supreme Court states that it is possible to cancel the arbitration award on the grounds outside of Article 70. In addition, the inconsistency of the judicial body in the cancellation of arbitration award occurs in the use of court decisions which first prove whether or not the matters contained in Article 70 of Law No. 30 of 1999. The Supreme Court in one of its decisions requires a court ruling that proves the existence of false documents or deception or concealment of documents. But in another decision, the Supreme Court granted the request for the cancellation of the arbitration award on the basis of Article 70 of Law No. 30 of 1999 even without a court ruling that proves the existence of false documents, deception, or concealment of documents.

According to Kantaatmadja (2001: 76), community culture as a problem is crucial in resolving disputes. He revealed 4 (four) of these cultural problems. Two of the main ones are a reluctance to implement an arbitration decision. The second is an effort to stall time as a tactic for not carrying out its obligations. Disputes regarding the cancellation of foreign arbitration decisions (and resistance to domestic arbitration decisions), which often arise lately, may be seen in the scope of this culture (Adolf, 2009: 5).

Certainty is a definite matter (condition) or provision (Kansil, 2009: 385). The law must be definite and fair. It must be a guideline for behavior and fairness because the behavior guideline must support an order that is considered reasonable. The law can only perform its functions if it has fairness and certainty. According to Kansil, certainty and justice are not just moral demands but factually characterize a law. A law without fairness and certainty is not just a bad law but not a law at all. Both of these characteristics include understanding the law itself (den begriff des rechts) (Shidarta, 2006: 70-80). Law is a collection of rules, the whole regulation of behaviors that applies in a shared life which can be enforced by a sanction (Salim Hs, 2010: 24). Legal certainty is a characteristic that cannot be separated from the law, especially for written legal norms. Law without the value of certainty will lose meaning because it can no longer be used as a guideline for everyone (Salim Hs, 2010: 82).

Legal certainty is a question that can only be answered normatively. Normative legal certainty is a rule made and promulgated with certainty because it regulates clearly and logically. Obviously, since it cause no doubt nor triggered multi-interpretation and is logical in the sense that it becomes a norm system along with other norms so that it does not clash or cause norm conflicts. The norm conflict caused by rule uncertainty can be in the form of norm consensus, norm reduction, or norm distortion. Legal certainty refers to the enforcement of clear, permanent, and consistent laws which cannot be influenced by subjective conditions. The importance of legal certainty in accordance with Article 28D paragraph 1 of the third amendment to the 1945 Constitution that "every person has the right to recognition, a guarantee of protection, and fair legal certainty and equal treatment before the law."

Kusumaatmadja (1999: 3) states that to achieve order there is legal certainty in human relations in society since it is impossible for humans to optimally develop their talents and abilities God has given them without legal and order certainty. Furthermore, Rahardjo (2006: 17) states that to establish a law state requires a long process, not only legal regulations that must be managed properly, but also needs a strong institution with extraordinary and independent authorities, and being free from intimidation or executive and legislative interference. It should be carried out by human resources with good morals and moral tested to be able to avoid the scheme and realize a legal certainty as a requirement for justice.

\section{Conclusions}

The principle of good faith in the arbitration agreement has not given an understanding of the meaning of good faith. This is due to the lack of limitation and definition of good faith concept in the law that gives opportunities to those who do not have good intentions to find loopholes and willing to cancel the arbitration award. The research indicates that good faith must be formulated as "the attitude or behavior adheres to the agreement to give the opponent the promise of his right and not to look for loopholes to 
escape from what has been agreed based on propriety and rationality. Sticking to the agreement means being ready to accept and implement the legal consequences arising from the agreement; while not looking for loopholes to escape means no deceiving, cunning, making things up, and doing inappropriate methods in a legal and social perspective as an effort to avoid legal consequences of what has been agreed that cause harm to others."

The manifestation of arbitral award transportation is an attempt to avoid the implementation of a final and binding arbitration award. Efforts to overcome the harm in good faith in order to maintain the superiority of arbitration as a method of dispute resolution associated with the goal of realizing legal certainty is to add a special procedure such as dismissal in the arbitration procedure. The procedure serves to filter the reasons for submitting the cancellation of the award and make it consistent with what has been determined by the law. It also functions as a means for the judge to see whether there is a good faith underlying the request. Requests for arbitration award cancellation that does not meet the provisions of the law and is not based on good faith cannot be submitted to the next hearing. With this procedure, the cancellation of the award can be minimized so that it can provide legal certainty for the parties.

\section{References}

Adolf, H. (2009). Syarat Tertulis dan Independensi Klausul Arbitrase. Buletin Triwulan Arbitrase Indonesia No. 6.

Coben, M.L. and Olson, K. C. (1992). "Legal Research in A. Nutshell, St. Paul". Minnesotta: West Publishing Company.

Fajar, M. and Yulianto, A. (2010). "Dualisme Penelitian Hukum Normatif dan Empiris". Yogyakarta: Pustaka Pelajar.

Fuady, M. (2003). "Arbitrase Nasional, Alternatif Penyelesaian Sengketa". Bandung: Citra Aditya Bakti.

Fuller, L.L. and Eisenberg, M.A. (1972). "Basic Contract Law". St. Paul-Minn: West Publishing Co.

Gautama, S. (1996). "Aneka Hukum Arbitrase (Ke Arah Hukum Arbitrase Indonesia yang Baru)". Bandung: Citra Aditya Bakti.

Hutagalung, S.M. (2012). "Praktik Peradilan Perdata dan Alternatif Penyelesaian Sengketa". Jakarta: Sinar Grafika.

Juwana, H. (2002). "Hukum Ekonomi dan
Hukum Internasional". Jakarta: Lentera Hati,

Kansil, C.S. (2009). "Kamus Istilah Hukum." Jakarta: Jala Permata Aksara.

Kantaatmadja, K. (2001). "Beberapa Masalah dalam Penerapan ADR di Indonesia." Bandung: Citra ditya Bakti.

Khairandy, R. (2011). Landasan Filosofis Kekuatan Mengikatnya Kontrak. Jurnal hukum Edisi Khusus, 18 (4), pp. 1-15

Kusumaatmadja, M. (1999). "Pengantar Ilmu Hukum, Suatu Pengenalan Pertama Ruang Lingkup Berlakunya Ilmu Hukum." Bandung: Alumni.

Marzuki, P.M. (2005). "Penelitian Hukum." Jakarta: Prenada Media.

Nasution. (2003). "Metode Penelitian Naturalistic." Bandung: Tarsito.

Patrik, P. (1994). "Dasar-Dasar Hukum Perikatan (Perikatan yang Lahir dari Perjanjian dan dari Undang-Undang)." Bandung: Mandar Maju.

Prodjodikoro, W. (1981). "Azas-Azas Hukum Perjanjian." Bandung: Bale.

Rahardjo, S. (2006). "Membedah Hukum Progresif." Harian Kompas.

Rajagukguk, E. (2000). "Arbitrase Dalam Putusan Pengadilan." Jakarta: Chandra Pratama.

Redfern, A. and Hunter, M. (1986). "Law and Practice of International Commercial Arbitration". London: Sweet and Maxwell.

Salim, H. (2010). "Perkembangan Teori Dalam IImu Hukum." Jakarta: Raja Grafindo Persada.

Sharma, K.M. (2002). "Pilihan Hukum dan Pilihan Forum dalam Kontrak Internasional". Jakarta: Program Pascasarjana FH UI.

Shidarta. (2006). "Moralitas Profesi Hukum Suatu Tawaran Kerangka Berfikir." Bandung: Revika Aditama.

Soekanto, S. and Pamuji, S. (2009). "Penelitian Hukum Normatif". Jakarta: Raja Grafindo Persada.

Soemartono, G. (2003). "Analisa Yuridis Keefektifan Penggunaan Arbitrase Internasional (UNCITRAL) Melawan Pertamina". Jakarta: Lembaga Penelitian dan Publikasi Ilmiah Universitas Tarumanegara.

Subekti, R. (2002). "Hukum Perjanjian". Jakarta: Intermassa.

Sudiarto and Asyhadie, Z. (2004). "Mengenal Arbitrase, Salah Satu Alternatif Penyelesaian Sengketa Bisnis". Jakarta: Grafindo Persada.

Suryodiningrat. (1985). "Azas-Azas Hukum Perikatan." Bandung: Tarsito. 